\title{
The antisickling effects of some edible vegetables
}

\author{
R. N. NWAOGUIKPE \\ Clinical Biochemistry Unit, Department of Biochemistry, Federal University of Technology, \\ P.M.B.1526 Owerri, Imo State, Nigeria. \\ E-mail: coconacik@yahoo.com
}

\begin{abstract}
The antisickling effects of the extracts of three vegetables highly consumed in Nigeria were investigated which included: Allium cepa (Onion), Allium sativum (Garlic) and Telferia occidentalis (Ugu). The extracts were partitioned into, the fat-soluble (FAS), the water-soluble (WAS), the butanol-soluble (BUS) and the crude aqueous extracts (CAEs) respectively. Free amino acid concentrations of the extracts expressed in $\mathrm{mg} / 100 \mathrm{~g}$ are: Telferia occidentalis WAS (600 \pm 0.1$)$, BUS $(242 \pm 0.11)$, FAS (175 \pm 0.11$)$ and CAE $(2890 \pm 0.1)$; Allium

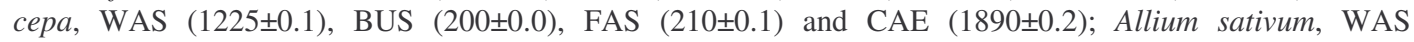
(900 \pm 0.1$)$, BUS $(225 \pm 0.2 \mathrm{mg})$, FAS $(120 \pm 0.11 \mathrm{mg})$ and CAE $(2800 \pm 0.2 \mathrm{mg})$ respectively. The total vitamin C concentration of the samples expressed in $\mathrm{mg} / 100 \mathrm{~g}$ are: Telferia occidentalis, WAS $(750 \pm 0.2)$, CAE

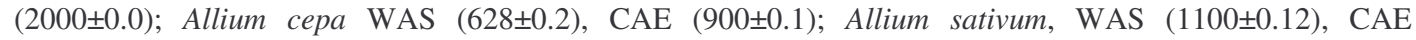
(2100 \pm 0.11$)$. Hemoglobin polymerization inhibition and the relative percent inhibition were estimated: Telferia occidentalis WAS (69.63\%), BUS (29.91\%), FAS (24.77\%) and CAE (75.27\%); Allium sativum, WAS (93.73\%), BUS (90.95\%), FAS (89.79\%) and CAE (95.43\%); Allium cepa, WAS( 26.61\%), BUS ( 40.19\%), FAS $(31.31 \%)$ and CAE (60.28\%) respectively. Amino acid analysis revealed the following: Phe, Arg, Lys, Ser, Met and others. All fractions of the samples exhibited high level of improvement in the $\mathrm{Fe}^{2+} / \mathrm{Fe}^{3+}$ ratio: Telferia occidentalis, (19.74-50.64\%), Allium cepa (108.10-114.84\%) and Allium sativum (287.50-400.21\%). Based on the free amino acid, the vitamin $\mathrm{C}$ concentrations, the inhibition of HbSS polymerization and the improvement in the $\mathrm{Fe}^{2+} / \mathrm{Fe}^{3+}$ ratio, these vegetables/extracts would nonetheless provide adequate nutritional and antisickling effectiveness necessary for the management of sickle cell disease and other related syndromes. (C) 2009 International Formulae Group. All rights reserved.
\end{abstract}

Keywords: Vegetable extracts, free amino acids, vitamin C, sickle cell disease, hemoglobin.

\section{INTRODUCTION}

Sickle cell disease SCD) is one of the most outstanding and highly researched genetic disorders that has had devastating and debilitating consequences in the subtropical and tropical regions of the world. The syndrome is inherited as a doublehomozygous existence or the acquisition of the heterozygous state of the HbSS or HbAS gene by both parents. Since the time of Herrick (1910), scientists and biochemists alike have not relented in the search for the therapy and other procedures for alleviating the excruciating pains and other symptoms associated with the disease (John et al., 1983;
Adachi and Asukara, 1982). Many chemical agents including peptides, tripeptides, hydroxyurea (HU), pyridoxal phosphate, zinc, short and long chain fatty acids, tucaresol, erythropoietin, amino acids , vitamins and minerals have all been tested on their possible role in inhibiting gelation or polymerization and the stabilization of the erythrocyte membrane (Lewis and William, 2008; Goldberg et al.,1992; Agbai, 1986).The current approach in the management of sickle cell disease focuses on the possible role of nutrition and this has yielded promising results( Ekeke, 1997; Uzoegwu ,1995). It is obvious that other treatment patterns have 
been developed, such as gene replacement therapy and the use of stem cells (Kumar and Clark, 1999). It has also been known that sickle cell disease patients are deficient of some vital nutrients such as Zn, Vit. C, amino acids with the resultant precipitation of chronic anemia and the shortening of the life span of erythrocytes. Ciklervit ${ }^{\mathrm{TM}}$, is an antisickling nutrient marketed by Niemeth Pharmaceutical Company in Nigeria. It consists of amino acids, vitamins and food extracts, and has proved a frontline nutrient for the management of SCD in Nigeria and some other African countries (Ekeke, 1997). Recently, another potent antisickling agent NICOSAN $^{\mathrm{TM}}$, a phytochemical preparation has been introduced for the management of SCD. The mechanism of action of the drug is based on its ability to increase oxygen affinity and the reversion of already sickled cells (Efemwonkiekie et al., 2002; Eaton and Hofricher, 1990; Charache et al., 1995; Iyamu et al., 2002). Telferia occidentalis (Ugu) is a leafy- green vegetable highly consumed and used for preparing different types of food like salads, soups and even the squeezed green leaves (green drink) is taken in folkloric medicine as an antidote for anemia (Akindahunsi, 2005). Although much has not been documented about this vegetable, there has been a wide belief of its nutritional and medicinal roles as a source of antioxidants, phytochemicals and minerals including some vitamins such as vitamins $A, B_{1}, B_{2}, C$, E, the carotenes, saponins and flavonoids (Akindahunsi, 2005). Onions (Allium cepa) is a member of the family Allicial; it is the most important of the seven species in the genus, Allium. The demand for the vegetable is common world -wide. The immature and the matured bulbs are eaten raw, fried or eaten as vegetable. They are used in preparation of soups, sauces, salads and for seasoning many other foods ( Rivlin, 2001; Lawson, 1998; Pinto and Rivlin, 1999; Okoli et al., 2007).

Allium sativum (Garlic), has been proclaimed a versatile herb and possess antioxidant properties (Phillistin and James, 2000). The sulphydryl compounds in garlic are potent chelators of toxic heavy metals .They are effective protectants against peroxidation and free radical damage to cells and organs .Garlic aids in the detoxification of peroxides such as hydrogen peroxide. It contains anti -oxidant nutrients such as Vit $\mathrm{C}$, $\mathrm{B}_{1}, \mathrm{~B}_{2}, \mathrm{~B}_{6}$ and Vit. $\mathrm{A}$, including selenium. Aged garlic extract (AGE) substantially boosts garlic anti-oxidant potential .AGE protects against DNA damage, keeps blood vessels fit, prevents against heart disease by reducing blood cholesterol level, preventing blood clots and lowers blood pressure through one of its components (methyl allyl trisulphide), which dilate blood vessels(Pinto and Rivlin, 1999; Okoli et al., 2008). It contains an amino acid derivative, Alliin, the enzyme Alliinase converts Alliin to Alliicin .Alliicin has antibiotic effects (Phyllistin and James, 2000). The main objective of this work is to determine the antisickling effects of the extracts of the vegetable species, the proximate composition and the phytochemical profile of the extracts. The work is also aimed at determining the effect of the extracts on the $\mathrm{Fe}^{2+} / \mathrm{Fe}^{3+}$ ratio of sickle cell erythrocytes which is an essential parameter for assessing the oxygen affinity of erythrocvtes.

\section{MATERIALS AND METHODS \\ Equipment and reagents}

Spectrophotometer (Unicam Spectronic20), Amino acid analyzer- Technicon (TSM-I Model-DNA 0209) at the Zoology Research Laboratory, University of Jos, Nigeria. Ninhydrin reagent, normal saline, Dichlorophenolindophenol, Dichloromethane, Butanol, Sodium metabisulphite, all of analytical grade, were purchased from Sigma Biochemicals, London.

\section{Plant samples and batch extraction}

Three hundred grams (300 g) of each of the vegetable species were purchased from a local market at Owerri metropolis in Imo State of Nigeria. The samples were dried in an oven at $60{ }^{\circ} \mathrm{C}$ to dehydrate them. After dehydration, each of the dried samples was blended into fine powder. One hundred grams (100 g) of each of the powdered samples were used for batch extraction procedures. The samples were soaked in $200 \mathrm{ml}$ of dichloromethane for 72 hours to generate the fat-soluble (FAS) extract. After filtration, the filtrates were concentrated by rotary evaporation. The residues from the filtration process above were dried in vacuo and later re-soaked in 200 $\mathrm{ml}$ of methanol. After 72 hours, the methanol extracts of the samples were generated and 
concentrated to equal volumes for butanolwater partitioning.

\section{Crude aqueous extract (CAE) preparation}

One hundred grams $(100 \mathrm{~g})$ of each of the powdered samples were soaked in $200 \mathrm{ml}$ of distilled water for 48 hours. The solutions were filtered and each filtrate concentrated by rotary evaporation.

\section{Butanol-water partitioning}

Butanol-water partitioning was carried out with each of the methanol extracts. Twenty milliliters $(20 \mathrm{ml})$ of butanol and 20 $\mathrm{ml}$ of distilled water were mixed with each extract, then transferred to a separating funnel which was left standing for 48 hours. The two-liquid phase layers were then separated into the butanol-soluble (BUS) and the watersoluble (WAS) fractions respectively. The extracts were later concentrated by rotor evaporation to equal volumes.

\section{Preparation of blood samples}

Blood samples were collected from confirmed homozygous sickle cell disease patients who attended hospital at the Federal Medical Center, Owerri, Nigeria. The donors were informed of the research and they voluntarily consented to the demand of the staff of chemical pathology laboratory of the medical centre for blood donation. Portions of HbSS blood $(0.20 \mathrm{ml})$ were collected into citrate tubes. Erythrocytes were isolated from the blood samples by centrifugation at a gravitational force of $1500 \mathrm{x}$ g for 15 minutes using the bench centrifuge (Nickel-Electro Centrifuge). Following careful siphoning of the plasma with Pasteur pipette, the erythrocytes were by repeated inversion suspended in a volume of isotonic saline $(0.9 \% \mathrm{NaCl})$ equivalent to the siphoned plasma. The erythrocyte suspension was then frozen at $0{ }^{\circ} \mathrm{C}$, subsequently thawed to produce a hemolysate for the hemoglobin polymerization experiment.

\section{Sickle cell hemoglobin (HbSS) polymerization inhibition experiment \\ HbSS polymerization was assessed by the turbidity of the polymerizing mixture at $700 \mathrm{~nm}$ using $2 \%$ solution of sodium metabisulphite as a reductant or deoxygenating agent (Iwu et al., 1988). $4.4 \mathrm{ml}$}

of $2 \%$ solution of sodium metabisulphite $\left(\mathrm{Na}_{2} \mathrm{~S}_{2} \mathrm{O}_{3}\right), 0.5 \mathrm{ml}$ normal saline and $0.1 \mathrm{ml}$ hemoglobin, were pipetted into a cuvette, shaken and the absorbance reading taken at $700 \mathrm{~nm}$ every two minutes for 30 minutes. This represents the control. Distilled water was used as blank for all assays. $4.4 \mathrm{ml}$ of $2 \%$ $\mathrm{Na}_{2} \mathrm{~S}_{2} \mathrm{O}_{3}, 0.5 \mathrm{ml}$ of each extract and $0.1 \mathrm{ml}$ hemoglobin solution ( $\mathrm{HbSS}$ ) were pipetted into a cuvette and readings taken as above. The rates of hemoglobin polymerization inhibition by the extracts were estimated by calculating the tangent of a plot of average change in extinction or optical density $(\Delta \mathrm{OD})$ versus time in minutes. The rates were equally expressed as percentage with respect to the control which is sickle cell blood (HbSS).

\section{Determination of the vitamin C concentration of the samples \\ Determination of the vitamin $\mathrm{C}$ concentration of each of the CAE and WAS fractions was carried out by the methods of Lambert and Muir (1974).}

\section{Determination of the concentration of the} total free amino acid of the samples

The free amino acid concentrations of the extracts were determined with Ninhydrin reagent using Phenylalanine as standard and reading the developed color at $570 \mathrm{~nm}$ and extrapolating the values from a standard curve of phenylalanine. Ninhydrin in acetone $(0.1 \%)$ was diluted with distilled water in the ratio 1:4; the WAS and CAE 1:1 with distilled water, the BUS 1:1 with methylated spirit and the FAS 1:5 with methanol. Exactly $20 \mu \mathrm{l}$ each of the diluted extracts were added to $4 \mathrm{ml}$ portions of the diluted ninhydrin. The resulting solutions were heated to boiling for 5 minutes, cooled and the absorbance read in a spectrophotometer at $570 \mathrm{~nm}$ using distilled water as blank.

Determination of the major amino acid constituents of the extracts

This was carried out with the aid of Technicon Sequential Multisample Amino Acid Analyzer, TSM (Technicon Instruments Corporation, Dublin, Ireland) at the Postgraduate Laboratory, Zoology Unit, University of Jos, Nigeria. 
Determination of the $\mathrm{Fe}^{2+} / \mathrm{Fe}^{3+}$ ratio

The $\mathrm{Fe}^{2+} / \mathrm{Fe}^{3+}$ ratio was determined by the methods of Davidson and Henry (1974); Virgil and George (1976).

\section{RESULTS}

The results of all assays are shown in tables 1-5 below. The values in the tables are the Mean \pm S.D from triplicate determinations. Table 1 shows the total vitamin $\mathrm{C}$ concentration of the vegetables expressed in $\mathrm{mg} / 100 \mathrm{~g}$. Table 2 shows the total free amino acid concentration of different fractions of the extracts. Table 3 depicts the amino acid content of the crude aqueous extract of the samples. Table 4 shows the rate of polymerization and the relative percent inhibition of $\mathrm{HbSS}$ polymerization at $100 \mu \mathrm{M}$ Phe equivalence of the fractions of the extracts. Table 5 shows the in vitro effect of the WAS and CAE fractions on the
$\mathrm{Fe}^{2+} / \mathrm{Fe}^{3+}$ ratio of $\mathrm{HbSS}$ at $40 \mu \mathrm{M}$ Phe equivalence of the extracts.

\section{DISCUSSION}

Table 1 shows the total vitamin $\mathrm{C}$ concentration of the samples expressed in $\mathrm{mg} / 100 \mathrm{~g}$. The ascorbic acid concentration of Telferia occidentalis is very high when compared with that of Allium cepa while that of Allium sativum is comparable. This high level of antioxidant vitamin and some of the antisickling amino acids identified must have contributed to the antisickling potency of these samples (Ekeke and Shode, 1990; Noguchi and Schechter, 1978). Telferia occidentalis ranked highest in free amino acid concentration. Alliun cepa and Allium sativum are equally rich in free amino acid concentrations, this result compares favourably with the findings of Hassan and Umar (2006) on the vegetable specie,

Table 1: Total vitamin $C$ concentration of the vegetable samples.

\begin{tabular}{llccc}
\hline Samples & Fraction & Vol. of extract & Conc. $(\mathbf{m g} / \mathbf{m l})$ & Conc. $(\mathbf{m g} / \mathbf{1 0 0} \mathbf{g})$ \\
\hline Telferia & WAS & 50.0 & $15.0 \pm 0.1$ & $750.0 \pm 0.20$ \\
occidentalis & CAE & 100.0 & $20.0 \pm 0.0$ & $2000.0 \pm 0.0$ \\
\hline Allium cepa & WAS & 40.0 & $15.7 \pm 0.1$ & $628.0 \pm 0.20$ \\
& CAE & 45.0 & $20.0 \pm 0.1$ & $900.0 \pm 0.10$ \\
\hline Allium sativum & WAS & 40.0 & $27.5 \pm 0.1$ & $1100.0 \pm 0.12$ \\
& CAE & 60.0 & $35.0 \pm 0.1$ & $2100.0 \pm 0.11$ \\
\hline
\end{tabular}

Values in the table are the mean \pm SD of 3 determinations. Conc. = Concentration. WAS: water-soluble;

CAE: crude aqueous extract.

Table 2: Total free amino acid concentrations of different fractions of the extracts of samples.

\begin{tabular}{|c|c|c|c|c|}
\hline Samples & Fraction & $\begin{array}{c}\text { Volume of extract } \\
(\mathrm{ml})\end{array}$ & $\begin{array}{l}\text { Conc. } \\
(\mathrm{mg} / \mathrm{ml})\end{array}$ & $\begin{array}{c}\text { Conc. } \\
(\mathrm{mg} / 100 \mathrm{~g})\end{array}$ \\
\hline Telferia & CAE & 90.0 & $32.0 \pm 0.1$ & $2890 \pm 0.1$ \\
\hline \multirow[t]{3}{*}{ occidentalis } & WAS & 30.0 & $20.0 \pm 0.1$ & $600 \pm 0.1$ \\
\hline & BUS & 22.0 & $11.0 \pm 0.1$ & $242 \pm 0.11$ \\
\hline & FAS & 07.0 & $25.0 \pm 0.2$ & $175 \pm 0.11$ \\
\hline \multirow[t]{4}{*}{ Allium сера } & CAE & 45.0 & $42.0 \pm 0.0$ & $1890 \pm 0.2$ \\
\hline & WAS & 35.0 & $35.0 \pm 0.11$ & $1225 \pm 0.1$ \\
\hline & BUS & 20.0 & $10.0 \pm 0.11$ & $200 \pm 0.0$ \\
\hline & FAS & 10.0 & $21.0 \pm 0.2$ & $210 \pm 0.1$ \\
\hline \multirow{4}{*}{ Allium sativum } & CAE & 56.0 & $50.0 \pm 0.2$ & $2800 \pm 0.2$ \\
\hline & WAS & 45.0 & $20.0 \pm 0.1$ & $900 \pm 0.1$ \\
\hline & BUS & 15.0 & $15.0 \pm 0.1$ & $225 \pm 0.2$ \\
\hline & FAS & 05.0 & $24.0 \pm 0.1$ & $120 \pm 0.11$ \\
\hline
\end{tabular}

Values in the table are the mean \pm SD of 3 determinations. Conc. $=$ Concentration. FAS: fat-soluble; WAS: water-soluble; BUS: butanol-soluble; CAE: crude aqueous extract. 
Table 3: Amino acids identified in the CAE fraction of the samples

\begin{tabular}{ll}
\hline Samples & Amino acids identified \\
\hline Telferia occidentalis & Arg, Glu, Leu,Ala,Tyr, Met, His, Thr., Lys, Val, Ser, Asp, \\
& Pro \\
\hline Allium cepa & Ile, Leu, Lys, Met,Phe, Thr, Val, Glu, Pro, Arg, Tyr, His, \\
& Gly, Ala, Ser, Asp \\
\hline Allium sativum & $\begin{array}{l}\text { Ile,Leu,Met,Phe,Thr,Val, Arg,Tyr,His, Gly, Ala, Ser, Asp, } \\
\text { Ser,Asp,Glu,Pro, Lys }\end{array}$ \\
\hline
\end{tabular}

Table 4: the rates of polymerization and the relative percentage (\%) inhibition of $\mathrm{HbSS}$ at $100 \mu \mathrm{M}$ Phe equivalence of the FAS, BUS, WAS and CAE fractions of the samples.

\begin{tabular}{lllccc}
\hline Sample & $\begin{array}{l}\text { Concentration } \\
(\boldsymbol{\mu M})\end{array}$ & Fraction & $\begin{array}{c}\text { Rate of } \\
\text { Polymerization }\end{array}$ & $\begin{array}{c}\text { Relative \% } \\
\text { polymerization }\end{array}$ & $\begin{array}{c}\text { Relative \% } \\
\text { inhibition }\end{array}$ \\
\hline Control & ------ & ------ & $0.214 \pm 0.0^{\mathrm{a}}$ & $100.0^{\mathrm{a}}$ & $0.00^{\mathrm{a}}$ \\
\hline Vitamin C & 100 & ----- & $0.0504 \pm 0.1^{\mathrm{b}}$ & $25.20 \pm 0.1^{\mathrm{b}}$ & $74.80 \pm 0.1^{\mathrm{b}}$ \\
\hline L- Phe & 100 & ----- & $0.0019 \pm 0.01^{\mathrm{c}}$ & $12.38 \pm 0.2^{\mathrm{c}}$ & $87.62 \pm 0.1^{\mathrm{c}}$ \\
\hline Telferia & 100 & FAS & $0.101 \pm 0.01^{\mathrm{d}}$ & $75.2 \pm 0.1^{\mathrm{d}}$ & $24.80 \pm 0.0^{\mathrm{d}}$ \\
occidentalis & 100 & BUS & $0.150 \pm 0.01^{\mathrm{e}}$ & $70.1 \pm 0.1^{\mathrm{e}}$ & $29.9 \pm 0.0^{\mathrm{e}}$ \\
& 100 & WAS & $0.065 \pm 0.01^{\mathrm{b}}$ & $30.4 \pm 0.1^{\mathrm{b}}$ & $69.5 \pm 1.0^{\mathrm{b}}$ \\
& 100 & CAE & $0.025 \pm 0.01^{\mathrm{c}}$ & $11.7 \pm 0.1^{\mathrm{c}}$ & $88.3 \pm 0.0^{\mathrm{c}}$ \\
\hline Allium cepa & 100 & FAS & $0.147 \pm 0.01^{\mathrm{e}}$ & $68.7 \pm 0.0^{\mathrm{e}}$ & $31.2 \pm 1.0^{\mathrm{c}}$ \\
& 100 & BUS & $0.128 \pm 0.01^{\mathrm{e}}$ & $59.8 \pm 0.1^{\mathrm{e}}$ & $40.2 \pm 0.0^{\mathrm{e}}$ \\
& 100 & WAS & $0.157 \pm 0.01^{\mathrm{d}}$ & $73.4 \pm 0.2^{\mathrm{d}}$ & $26.5 \pm 1.0^{\mathrm{d}}$ \\
& 100 & CAE & $0.105 \pm 0.01^{\mathrm{f}}$ & $49.0 \pm 0.0^{\mathrm{f}}$ & $50.0 \pm 1.0^{\mathrm{f}}$ \\
\hline Allium & 100 & FAS & $0.125 \pm 0.01^{\mathrm{e}}$ & $58.4 \pm 0.1^{\mathrm{e}}$ & $41.5 \pm 1.0^{\mathrm{e}}$ \\
sativum & 100 & BUS & $0.065 \pm 0.01^{\mathrm{b}}$ & $30.4 \pm 0.2^{\mathrm{b}}$ & $69.6 \pm 0.0^{\mathrm{b}}$ \\
& 100 & WAS & $0.035 \pm 0.01^{\mathrm{b}}$ & $16.8 \pm 0.1^{\mathrm{b}}$ & $83.2 \pm 0.0^{\mathrm{b}}$ \\
& 100 & CAE & $0.013 \pm 0.01^{\mathrm{c}}$ & $5.8 \pm 0.1^{\mathrm{c}}$ & $94.1 \pm 1.0^{\mathrm{c}}$ \\
\hline Values Value in & the & & &
\end{tabular}

Values Values in the table are the mean \pm SD of 3 determinations.

The values in the table with the same superscript on the same row are significantly different at $95 \%$ confidence level ( $\mathrm{p} \leq$ 0.05). Values with the same superscript on the same column are not significantly different at the same confidence level above. FAS: fat-soluble; WAS: water-soluble; BUS: butanol-soluble; CAE: crude aqueous extract.

Table 5: In vitro effect of was and CAE fractions on the $\mathrm{Fe}^{2+} / \mathrm{Fe}^{3+}$ ratio of $\mathrm{HbSS}$ blood at $40 \mu \mathrm{M}$ Phe equivalence of the samples

\begin{tabular}{llcccc}
\hline Sample & Fraction & \% Hb & \% $\mathbf{~ m H b}$ & $\mathbf{F e}^{\mathbf{2 +}} / \mathbf{F e}^{\mathbf{3 +}}$ & \% $\mathbf{I n c r e a s e}$ \\
\hline HbSS blood & Control & $93.37 \pm 1.0$ & $6.63 \pm 0.1$ & $14.08 \pm 0.2^{\mathrm{a}}$ & $0.00 \pm 0.0^{\mathrm{a}}$ \\
\hline Vitamin C & --- & $96.27 \pm 0.1$ & $3.73 \pm 0.2$ & $25.81 \pm 0.1^{\mathrm{b}}$ & $83.31 \pm 0.1^{\mathrm{b}}$ \\
\hline L- Phe & --- & $97.20 \pm 0.0$ & $2.80 \pm 0.1$ & $34.71 \pm 0.1^{\mathrm{c}}$ & $146.5 \pm 0.2^{\mathrm{c}}$ \\
\hline Telferia & CAE & $94.40 \pm 0.0$ & $5.60 \pm 0.0$ & $16.86 \pm 0.2^{\mathrm{d}}$ & $197.0 \pm 0.0^{\mathrm{d}}$ \\
occidentalis & WAS & $95.40 \pm 0.1$ & $4.60 \pm 1.0$ & $21.22 \pm 0.1^{\mathrm{e}}$ & $50.6 \pm 0.0^{\mathrm{e}}$ \\
\hline Allium cepa & CAE & $96.70 \pm 0.0$ & $3.30 \pm 0.2$ & $29.30 \pm 0.0^{\mathrm{f}}$ & $108.1 \pm 0.1_{\mathrm{f}}$ \\
& WAS & $96.80 \pm 0.1$ & $3.20 \pm 0.1$ & $30.25 \pm 0.1^{\mathrm{g}}$ & $114.8 \pm 0.2^{\mathrm{g}}$ \\
\hline Allium sativum & CAE & $98.20 \pm 0.1$ & $1.80 \pm 0.0$ & $54.56 \pm 0.2^{\mathrm{h}}$ & $287.5 \pm 0.1^{\mathrm{h}}$ \\
& WAS & $98.60 \pm 0.1$ & $1.40 \pm 0.2$ & $70.43 \pm 0.1^{\mathrm{i}}$ & $400.2 \pm 0.0^{\mathrm{i}}$ \\
\hline
\end{tabular}

Values in the table are the Mean \pm S.D for triplicate $(n=3)$ determinations.

The values on the rows with the same superscript are significantly the same and are significantly different along the column at $95 \%$ confidence level $(\mathrm{p} \leq 0.05)$. WAS: water-soluble; CAE: crude aqueous extract. 
Mormodica balsamina leaves. The free amino acid concentration observed here is an added advantage to the sickle cell disease patient whose system is under constant flux of nutrient degradation. This can be seen in table 2. From this pool of free amino acids, net protein synthesis is ensured. The consumption of these vegetables is highly recommended for sickle cell disease patients and other patients having related syndromes. Table 3 shows the different amino acids identified in the crude aqueous extracts of the samples, both essential and non-essential are prominent. There is also a preponderance of antisickling amino acids in all the samples. Some of the amino acids include: Phe, Lys, Arg, Tyr, Glu etc. Some of these amino acids have been found by some workers to inhibit polymerization and also reverse already sickle cells (Ekeke and Shode, 1990; Uwakwe and Nwaoguikpe, 2008; Noguchi and Schechter, 1978). Table 4 shows the inhibition of HbSS polymerization by the various fractions of the samples. The table also shows the relative percent polymerization and the relative percent inhibition. The CAE fractions exhibited the following level of inhibition: Allium sativum 94.2\%; Allium cepa $51.0 \%$ and Telferia occidentalis, $88.3 \%$. Allium sativum exhibited the highest level of inhibition of $94.2 \%$ followed by the CAE fraction of Telferia occidentalis. Other fractions of the extracts exhibited varying levels of inhibition ranging from $24.8 \%$ for the FAS of Telfaria occidentalis to $41.6 \%$ for the FAS of Allium sativum. Table 5 shows the $\mathrm{Fe}^{2+} / \mathrm{F}^{3+}$ ratio of sickle cell blood in the presence of the extracts compared with the control and those of L-Phe and vitamin C respectively. The increase in the $\mathrm{Fe}^{2} / \mathrm{Fe}^{3+}$ ratio is a positive indicator of their role in improving the oxidant status of sickle cell erythrocytes (Noguchi and Schechter, 1978). The ability of the sickle erythrocytes to revert to their normal morphology is due to increased oxygen affinity. It can be inferred that these vegetables/ spices can provide profound nutritional and antisickling effectiveness for the management of sickle cell disease.

Many antisickling agents that inhibited sickling in vivo by interacting with hemoglobin were abandoned because of the unacceptable doses that were required to inhibit sickling, resulting in such health complications as neutropenia,teratogenicity, etc (Oringer et al.,1994). In contrast, it has also been found that most antisickling agents eg. Amino acids, sugars, vitamins and peptides are devoid of toxicity (Ekeke and Shode, 1990; Ekeke et al, 2000, 2001; Nwaoguikpe and Uwakwe, 2005; Uwakwe and Nwaoguikpe, 2008) .The antisickling effects of the nutrients mentioned above are based on the following mechanisms. It has been elucidated that amino acids, peptides and sugars raise the minimum gelling concentration of $\mathrm{HbSS}$ such that the protein does not polymerize at physiological conditions (Diego and Jen, 1977; Dean and Schechter, 1978).These antisickling agents also inhibit sickling by binding at the hemepocket obstructing the protein-protein interaction required for fiber formation in gelation (Noguchi and Schechter, 1978; Diego and Jen, 1977 ; Efenwonkiekie et al., 2002). These extracts apart from inhibiting the polymerization process, improved the oxidant status of the erythrocytes by improving the $\mathrm{Fe}^{2+} / \mathrm{Fe}^{3+}$ ratio. The antisickling effect of these samples is similar to that of Cajanus cajan , a leguminous seed having pronounced antisickling effectiveness. The extracts of this leguminous specie stabilizes the erythrocyte membrabe, improve the oxidant status of HbSS erythrocytes and lowers the activity of LDH in both serum and plasma of sickle cell blood (Ekeke and Shode, 1990; Nwaoguikpe, 1999; Nwaoguikpe and Uwakwe, 2005). These extracts may present a double-prong effect in the management of sickle cell disease and other related syndromes such as anemia and thalassemia. The consumption of these vegetables/spices would not only minimize the pathophysiological complications of the syndrome but would also proffer good healthy conditions for sickle cell disease patients.

\section{REFERENCES}

Akindahunsi AA, Salawu SO. 2005. Phytochemical screening and nutrientantinutrient composition of selected tropical green leafy vegetables. African Journal of Biotechnology, 4(6): 497-501.

Adachi K, Asukara T. 1982. Kinetics of the polymerization of hemoglobin in high and low phosphate buffers. Blood Cells, 8: $213-224$. 
Agbai O. 1986. Antisickling effects of dietary thiocyanate in the prophylactic control of sickle cell anemia. J. Natl. Med. Assoc., 78: 1053-1056.

Charache S, Terrivin ML, Moore RD, Dower G. 1995. Effects of Hydroxyurea (HU) on the frequency of painful crises in sickle cell anemia and the investigators of the multicenter study on the effects of hydroxyurea on sickle cell. New Engl. J. Med., 332: 1317-1322.

Davidson J, Henry JB. 1974. Clinical Diagnostics by laboratory methods. Todd-Sanford, W.B. Saunders: Philadelphia, 112, 1380

Dean JMD, Schechter AN. 1978. Sickle cell anemia: Molecular and cellular bases of therapeuticapproaches (third of three parts). New England Journal of Medicine., 299 (16): 863-869.

Diego K , Jen TY. 1977. Oligopeptides as potential antiaggregation agents deoxyhemoglobinS. Proceedings Natl. Acad. Sci., 74: 5461-5463.

Efemwonkiekie WI, Ernest AT, Torsio A. 2002. In vitro effect of NIPRISAN ( NIX0699, a naturally occurring potent antisickling agent. Brit. J. Hematology, 118: 337-342.

Ekeke GI, Shode FO. 1990. Phenylalanine is the predominant antisickling agent in Cajanus cajan seed extract. Planta Medica., 56: 41-43.

Ekeke GI, Uwakwe AA, Nwaoguikpe RN. 2000. Edible legumes as beneficial antisickling agents. Nigerian Journal of Biochemistry and Molecular Biology, 16: 200-203.

Ekeke GI, Uwakwe AA, Nwaoguikpe RN. 2001. The Action of ripe fruit juices on Hemoglobin polymerization, $\mathrm{Fe}^{2+/} \mathrm{Fe}^{3+}$ ratio and lactate dehydrogenase (LDH) activity of sickle cell blood (HbSS). Nigerian Journal of Biochemistry and Molecular Biology, 16(1): 31-35

Eaton WA, Hofritcher J. 1990. Sickle cell hemoglobin polymerization [Review]: Archives in Protein Chemistry, 40: 63273.

Goldberg M, Brugnara C, Dover G, Schapira I.1990. Treatment of sickle cell disease with Hydroxyurea and Erythropoietin. New Engl. J. Med., 323: 366-372.
Hassan LG , Umar KJ. 2006. Nutritional value of Balsam Apple (Momordia balsamia L.) leaves. Pakistan Journal of Nutrition, 5(6): 552-559.

Head CA, Brugnara C, Dover G, Schapira I. 1997. Low concentrations of Nitric oxide increases oxygen affinity of sickle erythrocytes in vivo and in vitro. J. Clin. Invest., 110: 1193-1198.

Herrick JP. 1910. Peculiar elongated and sickle shaped erythrocytes in a case of severe anemia. Archives Internal Medicine, 6: 517.

Iyamu EW, Turner EA, Asukara T. 2002. Antisickling effect of NIX-0699. British Journal of Haematology, 118: 337-343.

Iwu MN, Igboko OO, Onwubiko H, Ndu UP. 1988. Effect of Cajanus cajan on gelation and oxygen affinity of sickle cell hemoglobin. J. Ethnopharmacol., 22: 99104.

John AK, Peter GT, Rudolfo B. 1983. Pyridoxal phosphate as an Antisickling agent in vitro. The Journal of Clinical Investigation, 71: 1224-1229.

Kumar P, Clark M. 1999. Hematological Diseases: Clinical Medicine $\left(4^{\text {th }}\right.$ edn). W.B. Saunders: Edinburg; 353-362.

Lambert J, Muir TA. 1974. Estimation of Vitamin C: Practical Chemistry ( $3^{\text {rd }}$ edn). Heinneman Publishers Intl. bks.: London.

Lawson LD. 1998. Garlic, a review of its medicinal effects and indicated active compounds. In Phytomedicines of Europe, chemistry and biological activity. ACS Symposium, Series 691, pp. 176209.

Lewis H, William M. 2008. Diet and Nutrition in Sickle Cell Disease. SEARCH drSpock; 1-3.

Nwaoguikpe RN. 1999. The effects of extracts of some foodstuffs on Lactate dehydrogenase (LDH) activity and Hemoglobin polymerization of sickle cell blood. Ph.D thesis, University of Portharcourt, Nigeria, pp. 88-102.

Nwaoguikpe RN, Uwakwe AA 2005. The antisickling effects of dried fish (Tilapia) and dried Prawn (Astacus red). J. Appl. Sci. Environ. Mgt., 9(3): 115-117.

Noguchi CT, Schetcher AN. 1978. The inhibition of sickle cell hemoglobin by amino acids and related compounds. Biochemistry, 17: 5455-5459. 
Okoli RI, Aigbe OO, Ohaju-Obodo JO, Mensah, JK. 2007. Medicinal herbs used for managing some common ailments among Esan people of Edo state, Nigeria. Pakistan Journal of Nutrition, 6(5): 490496.

Oringer EP, Abraham DJ, Parker JC. 1994. Development of Drug therapy in Sickle Cell Disease, Basic Principles and Related Practice. Ravel Press: New York.

Pinto JT, Rivlin RS. 1999. Garlic and other Allium vegetables in cancer prevention. In Nutritional Oncology, Haber D, Blackburn G, Go ULM (eds). Academic Press: San Diego, CA; 393-403.

Phyllistin AB, James FB. 2000. Tips for Preventing Food Poisoning "Herbs"
Americas No.1 Guide to Natural Health ( $3^{\text {rd }}$ edn). Publ. Averg: New York; 383398.

Rivlin RS. 2001. Recent Advances in the Nutritional effects associated with the use of Garlic as a supplement. Journal of American Society of Nutrition, 131: 951 $-954$.

Uwakwe AA, Nwaoguikpe RN. 2008. In Vitro antisickling effects of Xylopia aethiopica and Monodora myristica. Journal of Medicinal plant Research, 2(6): 119-124.

Uzoegwu PN. 1995. Management of Sickle Cell Disease: Families Guide Against Sickle Cell Disease ( $1^{\text {st }}$ edn). Snap Press Limited: Enugu, Nigeria. 